\title{
Analisis Kontestasi Kelembagaan DPD Dan Upaya Mengefektifkan Keberadaannya
}

\author{
Oleh: Masnur Marzuki \\ Dosen FH UII Yogyakarta \\ e-mail:masnur_marzuki@yahoo.com
}

\begin{abstract}
In considering the principle of check and balances in legislature matter, the grand theme should be proposed in this context is how to guarantee checks and balances within the legislative branch and that principle are implemented properly and reliably. Nonetheless, in Indonesian constitutional system after the Reformation era when the House of Regional Representative (DPD) was established, the achivement of check and balances is still far from its fundamental aim. As a result, the "new" Constitution is challenged to observe an ideal parliament system where checks and balances within the legislative branch can be achieved and the existence of such fundamental institution could effectively bridge local aspiration to national policy.
\end{abstract}

Keywords: DPD, lembaga perwakilan, demokrasi

\section{Pendahuluan}

Dalam logika transisisi demokrasi, melakukan restrukturisasi dan revitalisasi institusi-institusi demokrasi adalah sebuah keniscayaan. Hal itu dimaksudkan agar sistem politik demokrasi dapat segera diwujudkan. Di samping itu, proses revitalisasi tersebut semakin urgen keberadaannya dalam rangka mempercepat proses demokratisasi yang diharapkan bermuara pada perbaikan kesejahteraan rakyat. Berkaitan dengan itu, Robert Dahl mengemukakan perlunya sebuah konstitusi yang demokratis agar keberadaan institusi-institusi demokrasi yang sudah dan akan dibentuk itu dapat bekerja dengan maksimal. ${ }^{1}$

Dalam konteks Indonesia, konstitusi hasil perubahan telah melahirkan beberapa lembaga-lembaga negara baik dalam cabang kekuasaan legislatif

${ }^{1}$ Robert Dahl, On Democracy, edisi terjemahan Bahasa Indonesia, Perihal Demokrasi, Yayasan Obor, Jakarta, 2001, hlm. 179. 
maupun yudikatif. Dalam cabang kekuasaan legislatif misalnya, konstitusi hasil perubahan tersebut telah melahirkan Dewan Perwakilan Daerah Republik Indonesia (DPD RI) sebagai lembaga baru yang akan menjamin terwujudnya hubungan pusat dan daerah yang lebih baik dan bertanggungjawab. Realitas ketidakadilan dan kurang meratanya pembangunan di tingkat pusat dan daerah selama Orde Baru telah memicu keinginan perlunya melembagakan aspirasi daerah dari yang dulunya berwujud Utusan Daerah menjadi Perwakilan Daerah. Bahkan pada awalnya muncul wacana diberlakukannya sistem negara federal di Indonesia sebagai jalan keluar ketidakadilan yang selama ini dirasakan beberapa daerah seperti Aceh, Riau dan Papua.

Untuk itulah keberadaan DPD RI dalam desain bangunan ketatanegaraan Indonesia dimaksudkan untuk menjembatani aspirasi lokal kedaerahan dengan kebijakan pembangunan nasional. ${ }^{2}$ Dengan demikian kepentingan dan aspirasi lokal dapat terintegrasi dan selaras dengan kebijakan pusat. Bagaimanapun aspirasi kedaerahan harus tetap menjadi perhatian apalagi mengingat luasnya wilayah Indonesia dan semakin kompleksnya masalah yang dihadapi dan berbagai ancaman disintegrasi atau pemisahan diri beberapa daerah yang menganggap tidak pernah diperhatikan aspirasi dan kesejahteraannya oleh pemerintah pusat. $^{3}$ Intinya DPD diharapkan menjadi perekat yang akan memperkuat ikatan daerah-daerah dalam wadah Negara Kesatuan Republik Indonesia. Itulah yang menjadi pertimbangan politis untuk melahirkan DPD.

Lebih jauh, kelahiran DPD RI juga dimaknai sebagai optimalisasi lembaga perwakilan Indonesia. Kebutuhan sistem parlemen dua kamar menjadi urgen mengingat perlunya jaminan mekanisme check and balances dalam lembaga perwakilan itu sendiri. R. Hogue dan Martin Harrop berpendapat; "the main justification for having two (or occasionally more) chambers within an assembly ar first, to present disticnt interest within society and secondly to provide checks and balances within the legislative branch." (Pembenaran yang paling utama kenapa perlu ada dua kamar dalam satu rumah (parlemen) adalah pertama, menegaskan perbedaan kepentingan dalam masyarakat dan kedua untuk memastikan adanya mekanisme check

\footnotetext{
${ }^{2}$ Kelompok DPD di MPR RI, Untuk Apa DPD RI, Jakarta, 2005, hlm. 18.

${ }^{3}$ Beberapa daerah yang sempat menyatakan ingin memisahkan diri dari Negara Kesatuan Republik Indonesia anatara lain Nanggro Aceh Darussalam, Riau dan Papua. (Lihat; Ibid.)
} 
and balance dalam cabang kekuasaan legislatif. ${ }^{4}$ Dalam kenyataannya, wewenang yang dimiliki oleh DPD sangat terbatas, DPD tidak dapat melaksanakan tugasnya secara optimal. Berdasarkan uraian tersebut, permasalahan yang menarik untuk dikaji adalah bagaimana upaya mengoptimalkan dan meningkatkan kinerja DPD sebagai kamar kedua di samping DPR?

\section{Wewenang DPD Dalam Struktur Ketatanegaraan Indonesia}

Pada awal rencana pembentukannya, DPD dimaksudkan sebagai salah satu kamar lain di parlemen di samping DPR. Jika saja itu terwujud, niscaya parlemen Indonesia sudah mengadopsi sistem bikameral (sistem parlemen dua kamar). Namun dalam perkembangan selanjutnya dalam pembahasan PAH I BP MPR periode 1999-2004, DPD yang dimaksudkan sebagai wakil masyarakat daerah hanya dibentuk sebagai lembaga pendukung bagi DPR. Dengan begitu tidak mengherankan bila lembaga tersebut hanya dibekali dengan kewenangan terbatas. Jimly Asshiddiqie mengatakan bahwa keberadaan DPD hanyalah sebagai co-legislator ketimbang peran sebagai legislator sesungguhnya. ${ }^{5}$ Pendapatnya itu didasarkan pada kenyataan di mana DPD tidak memiliki kewenangan membuat undang-undang. ${ }^{6}$ Padahal sebagai bagian dari parlemen selayaknya DPD juga memiliki kewenangan membuat undang-undang seperti yang juga dimiliki DPR.

Bila ditilik lebih jauh sebenarnya penyebutan sistem perwakilan Indonesia sebagai sistem bikameral tidak sepenuhnya tepat. Sistem perwakilan Indonesia sebenarnya lebih berwatak unikameral sebab selain DPD dan DPR masih terdapat MPR yang juga berkedudukan sebagai lembaga negara sebagaimana diatur dalam konstitusi dan UU No. 22 Tahun 2003 tentang Susunan dan Kedudukan MPR, DPR, DPD, dan DPRD. ${ }^{7}$

Dari aspek legitimasi kelembagaan, jika dibandingkan dengan DPR, sebenarnya DPD mempunyai legitimasi yang lebih kuat dalam hal

\footnotetext{
${ }^{4}$ R. Hogue dan Martin Harrop dalam Jimly Asshiddiqie, Konstitusi dan Konstitusionalisme Indonesia, Konstitusi Press, Jakarta, 2005.

${ }^{5}$ Ibid, hlm. 139

${ }^{6}$ Ibid.

${ }^{7}$ Ciri tersebut merupakan kekhasan sistem perwakilan Indonesia yang sering diistilahkan dengan sistem unikamreal berciri bikameral. (Lihat; NI'matul Huda, Lembaga-Lembaga Negara dalam Masa Trnasisi, UII Press, Yogyakarta, 2007, hlm. 101102.)
} 
dukungan riil politik dari rakyat. ${ }^{8}$ Sehingga dengan legitimasi yang dimiliki tersebut dibatasinya kewenangan DPD membuat undang-undang menjadi tidak proporsional. Senada dengan itu, peneliti dari Australian National University, Stephen Sherlock, berpendapat bahwa DPD merupakan contoh yang tidak lazim dalam praktek bikameral sebab meskipun punya legitimasi yang kuat, kewenangannya amatlah terbatas. ${ }^{9}$

Keterbatasan kewenangan DPD tersebut patut disayangkan sebab hal itu akan berujung pada tidak efektifnya keberadaan lembaga hasil reformasi tersebut. Sesuai dengan amanat UUD 1945 dan Undang-Undang Nomor 22 Tahun 2003 tentang Susunan dan Kedudukan Majelis Permusyawaratan Rakyat, Dewan Perwakilan Rakyat, Dewan Perwakilan Daerah, dan Dewan Perwakilan Rakyat Daerah (UU Susduk) maka kewenangan DPD RI meliputi:

1) Pengajuan kepada DPR RI rancangan undang-undang yang berkaitan dengan otonomi daerah, hubungan pusat dan daerah, pembentukan dan pemekaran serta penggabungan daerah, pengelolaan sumber daya alam dan sumber daya ekonomi lainnya, serta yang berkaitan dengan perimbangan keuangan pusat dan daerah.

2) Ikut membahas rancangan undang-undang yang berkaitan dengan otonomi daerah; hubungan pusat dan daerah; pembentukan, pemekaran, dan penggabungan daerah; pengelolaan sumber daya alam dan sumber daya ekonomi lainnya, serta perimbangan keuangan pusat dan daerah.

3) Memberikan pertimbangan kepada Dewan Perwakilan Rakyat atas rancangan undang-undang anggaran pendapatan dan belanja negara dan rancangan undang-undang yang berkaitan dengan pajak, pendidikan, dan agama.

4) Dapat melakukan pengawasan atas pelaksanaan undang-undang mengenai: otonomi daerah, pembentukan, pemekaran dan penggabungan daerah, hubungan pusat dan daerah, pengelolaan sumber daya alam dan sumber daya ekonomi lainnya, pelaksanaan anggaran pendapatan dan belanja negara, pajak, pendidikan, dan agama, serta menyampaikan hasil pengawasannya itu kepada DPR RI sebagai bahan pertimbangan untuk ditindaklanjuti.

${ }^{8}$ Seorang anggota DPD dari DKI misalnya memiliki dukungan jumlah pemilih yang jauh lebih besar ketimbang persentase dukungan seorang anggota DPR dari propinsi yang sama. Di samping itu, mereka juga dipilih langsung, tidak melalui parpol sebagaimana anggota DPR.

${ }^{9}$ Sekretariat DPD RI, Bikameral Bukan Federal, Jakarta, 2005, hlm. 76. 
5) Memberikan pertimbangan kepada DPR dalam pemilihan anggota Badan Pemeriksa Keuangan (BPK).

Sebenarnya pada DPD melekat fungsi dan kewenangan yang meski terbatas. Kewenangan itu berkaitan dengan pengajuan rancangan undang-undang tertentu, pengawasan pelaksanaan undang-undang, serta fungsi pertimbangan. Namun dalam prakteknya, fungsi dan kewenangan itu tidaklah berjalan efektif sesuai dengan semangat awal pendiriannya. Dalam hal pengajuan rancangan undang-undang tertentu misalnya, gerak langkah DPD dalam fungsi legislasi amat bergantung pada itikad DPR apakah pengajuan itu dapat diteruskan atau atau hanya berhenti menjadi usulan semata. Hal itu dikarenakan ketiadaan legitimasi yuridis DPD untuk menyusun rancangan undang-undang tertentu. Kalau pun ada, peran tersebut hanya berhenti sampai pada pengajuan rancangan undangundang saja.

Dalam pelaksanaan fungsi pengawasan, kondisi serupa juga terjadi seperti halnya dalam menjalankan fungsi legislasi. Hasil kerja pengawasan DPD yang dilakukan melalui Panita Ad Hoc dan badan-badan lain di DPD tidak memiliki implikasi apa-apa sebab hasil pengawasan tersebut harus melalui mekanisme penyerahan kepada DPR RI. Oleh DPR, hasil kerja DPD itu hanya dijadikan sebagai bahan pertimbangan untuk ditindaklanjuti. Fungsi pengawasan DPD tersebut hampir menjadi siasia sebab hasil kerja itu sebatas menjadi bahan masukan dan pertimbangan saja bagi DPR. Bila begitu, tak heran bila banyak kalangan menyebut DPD adalah staf ahlinya DPR.

Begitu juga dengan fungsi pertimbangan ketika pemilihan anggotaanggota Badan Pemeriksa Keuangan (BPK) dilaksanakan. Fungsi dan peran DPD tidak lebih dari sekedar pemberi masukan dan pertimbangan terkait penentuan siapa yang akan duduk menjadi anggota BPK.

Dengan kewenangan yang hampir-hampir tidak ada itu, wajar jika kemudian banyak pihak mengatakan bahwa keberadaan DPD tidak lebih dari sekedar staf ahli DPD yang bertugas memberi masukan dan pertimbangan belaka tanpa implikasi politis apa-apa bagi kepentingan yang diwakilinya. Jauh panggang dari api. Itulah ungkapan yang paling tepat menggambarkan DPD dalam format das sollen-nya dengan apa yang terlihat di lapangan (das sein). Filosofi awal agar lembaga baru tersebut mampu berfungsi sebagai penyeimbang kekuasaan baik eksekutif maupun legislatif sangat sulit terwujud. 
Bila diidentifikasi lebih jauh ada tiga penyebab utama yang menyebabkan kenapa DPD belum optimal dan efektif keberadaannya dalam konstelasi politik ketatanegaraan Indonesia. ${ }^{10}$ Pertama, sebagai lembaga negara yang baru DPD belum dapat menemukan format kerja dan struktur kelembagaan yang memadai. Hal ini menyebabkan keselarasan, kebutuhan strategis dan percepatan kinerja kelembagaan yang ideal belum terwujud. Kedua, bagaimanapun DPD berkomposisikan anggota-anggota yang notabene adalah muka-muka baru dalam dunia politik -meskipun beberapa nama sudah lama berkecimpung dalam perpolitikan nasioanal ${ }^{11}$ - sehingga cukup menyulitkan ketika berhadapan dengan kompleksitas masalah yang sedang dan akan dihadapi. Ketiga, kendala yuridis konstitusional baik UUD 1945 dan UU Susduk yang menghadapkan DPD pada kenyataan bahwa lembaga ini tidak memiliki fungsi keparlemenan yang selayaknya dimiliki lembaga seperti itu yakni fungsi legislasi.

Dari tiga kendala tersebut, kendala yang terakhir merupakan kendala yang paling berat dan kompleks untuk dituntaskan. Sebagaimana dimaklumi bersama bikameralisme Indonesia tidak ditemukan di negara manapun yang menganut sistem serupa. Di 22 negara kesatuan yang juga menganut sistem bikameral, kedua kamar di Parlemen memiliki peran yang hampir seimbang. Di Indonesia, DPD sejauh ini hanya memainkan peran sebatas perwakilan dalam bentuk kehadiran utusan daerah di pusat (representation in present) bukan perwakilan ideal dalam bentuk diperjuangkannya aspirasi daerah di tingkat pusat.

Berangkat dari fakta yuridis konstitusional dan politis tersebut, sebagai sebuah institusi politik DPD hampir bisa dikatakan sebagai lembaga negara yang betul-betul sumir. Tak sedikti pengamat menilai DPD telah bergerak menjadi lembaga yang kehilangan parameter hampir di segala bidang dan peran. Lembaga yang dipilih langsung konstituennya, namun tanpa melewati pijakan substansi keterwakilan. Institusi politik yang sudah kehilangan ukuran apakah mereka sedang maju atau mundur. Lembaga yang peta identifikasi dirinya makin terhapus, sebagai representasi rakyat di daerah.

${ }^{10}$ DPD RI, Kerja Politik Untuk Kesejahteraan Masyarakat dan Daerah; Rencana Kerja Strategis Dewan Perwakilan Daerah Republik Indonesia, Sekretariat Jenderal DPD, Jakarta, 2006, hlm. 31.

${ }^{11}$ Tokoh-tokoh yang bisa disebut perpengalaman dalam keanggotaan DPD seperti Ginandjar Kartasasmita, Sarwono Kusumaatmadja dan Laode Ida. 
Kepentingan daerah yang diamanatkan di pundak DPD dalam prakteknya tidak diintegrasikan ke ranah pengambilan keputusan legislasi nasional. Dari situlah terlihat bagaimana DPD termarjinalkan secara politik dan konstitusional. Padahal kepentingan daerah semestinya diperjuangkan secara proporsional dengan memberikan peran yang legitimate dan memiliki implikasi yuridis konstitusional dalam setiap pengambilan keputusan dan kebijakan nasional yang berimplikasi langsung terhadap daerah.

Bahkan bila menilik sejarah kelahirannya, jauh sebelum dibentuk DPD memang dipersiapkan memiliki keterbatasan dalam fungsi keparlemenan. Mayoritas fraksi-fraksi di PAH I MPR-RI periode 1999-2004 enggan memberikan kewenangan yang sejajar antara DPR dan DPD sebab khawatir DPD akan memperumit dan menghambat proses legislasi di DPR. ${ }^{12}$ Berdasarkan wawancara Valina Singka Subekti dengan Zain Badjeber, anggota Fraksi PPP, terungkap bahwa dengan keadaan yang ada di mana sudah dilakukan penyederhanaan dalam tahapan proses pembahasan undang-undang dari empat tahap menjadi dua tahap saja, DPR sudah kewalahan. Apalagi ditambah dengan DPD.

Dengan kondisi yang demikian, DPD tidak lebih dari aksesori atau pelengkap penderita dalam konsfigurasi politik keparlemenan di Indonesia. Moh. Mahfud bahkan mengistilahkan DPD sebagai lembaga formalitas konstitusional belaka. ${ }^{13}$ Ongkos politik yang mahal dan besarnya anggaran yang diperuntukkan bagi DPD akhirnya menjadi terbuang percuma sebab eksistensinya bisa diungkapkan sebagai lembaga yang "datangnya tidak menambah, perginya tidak mengurangi".

Bagaimanapun juga, agar DPD tidak menjadi lembaga yang sia-sia belaka keberadaannya maka diperlukan langkah-langkah strategis untuk dapat mengubah eksistensi DPD RI dari lembaga sekedar "ada" itu menjadi lembaga yang benar-benar ada dengan kesejatian. Langkahlangkah strategis tersebut antara lain dapat dilakukan dengan membekali DPD RI dengan kewenangan legislasi yang efektif.

Merujuk pada terminologi legislatif maka salah tugas paling penting dari sebuah parlemen adalah membuat peraturan perundang-undangan. Parlemen dalam satu konsfigurasi sistem politik demokratis mensyaratkannya menjadi institusi inti sebuah negara yang demokratis.

${ }^{12}$ Valina Singka Subekti, Menyusun Konstitusi Transisi, Raja Grafindo Persada, Jakarta, 2008, hlm. 259.

${ }^{13}$ Moh. Mahfud, Perdebatan Hukum Tata Negara, LP3ES, Jakarta, 2007, hlm. 68. 
Hal ini karena keberadaan lembaga itu akan mempengaruhi bekerjanya sistem politik dan ketatanegaraan. Maka jika lembaga seperti DPD RI disebut sebagai bagian dari parlemen, sudah selayaknya tugas penting membuat UU itu menjadi salah satu kerja inti DPD RI.

Secara yuridis normatif, pasca amandemen UUD 1945 proses legislasi nasional sebenarnya memang melibatkan tiga institusi yakni Presiden, DPR dan DPD RI (proses legislasi segi tiga). Namun realita di lapangan berbicara lain. DPD RI belum diberikan peran yang berimplikasi secara legal formal dalam setiap pengambilan keputusan dalam bidang legislasi. Hal ini dapat dilihat dari proses yang berjalan antara DPR dan DPD RI. DPD RI hanya memiliki peran konsultatif (Pasal 22D UUD 1945). Konstitusi dan UU Susduk hanya mengamanahkan DPD RI sebatas memberikan pandangan dan pendapat dalam pembahasan RUU pada pembicaraan awal tingkat satu. Dengan begitu DPD RI hanya sebagai penonton sebab pengambilan keputusan legislasi yang sesungguhnya ada di tangan DPR bersama Presiden.

Untuk itulah ke depan, DPD RI harus diposisikan sebagai salah satu bagian dalam Badan Kekuasaan Legislatif yang berhak dan berwenang merancang, membahas, dan mengesahkan suatu rancangan undangundang yang berkaitan dengan kepentingan dan aspirasi yang bersifat kedaerahan dengan memperhatikan penolakan dari Dewan Perwakilan Rakyat atau Presiden. Terhadap RUU yang diajukan Pemerintah dan DPR, DPD RI juga berhak dan berwenang menolak rancangan dan usul amandemen atas suatu Undang-Undang dan Rancangan UndangUndang tertentu yang berkaitan erat dengan kepentingan dan aspirasi lokal. ${ }^{14}$ Dengan begitu filosofi terjaminnya mekanisme check and balances dalam sistem perwakilan dapat diwujudkan secara nyata.

Pertanyaannya kini adalah bagaimana melegitimasi DPD RI itu agar masuk ke dalam ranah kekuasaan legislatif yang efektif? Tidak ada cara lain selain memasukkan rumusan substantif tersebut ke dalam materi perubahan konstitusi yang kini terus diupayakan oleh Kelompok DPD di MPR. Bagaimanapun perubahan konstitusi bukanlah hal yang mustahil dilakukan. Di samping dinamika ketatanegaraan yang kian hari semakin kompleks, salah satu butir hasil kajian Komisi Konstitusi juga menyebutkan bahwa hasil perubahan UUD 1945 yang telah dilakukan

${ }^{14}$ Usulan ini antara lain dikemukakan oleh Jimly Asshiddiqie. Lihat dalam Jimly Asshiddiqie, Konstitusi dan Konstitutisionlisme Indonesia, Konpress, Jakarta, 2005, hlm. 176. 
sebelumnya dalam beberapa hal mengandung kontradiksi konseptual sehingga sulit diwujudkan dalam praktek ketatangeraan. ${ }^{15}$

Meskipun begitu, upaya merintis perubahan konstitusi dalam rangka membekali DPD RI dengan kewenangan yang tegas dan autoritatif bukannya tanpa halangan. Pada paruh pertama tahun 2006, DPD RI pernah mengajukan amandemen konstitusi untuk menegaskan keberadaan dan fungsinya sebagai salah satu kamar di parlemen. Berbagai dukungan pun diperoleh baik yang bersifat kelembagaan maupun bersifat sosial kemasyarakatan. Beberapa fraksi seperti fraksi Kebangkitan Bangsa dan fraksi partai Demokrat telah menandatangani surat dukungan bagi DPD untuk melakukan perubahan konstitusi. Namun usaha itu gagal di tengah jalan karena belum mendapat dukungan dan apresiasi publik yang signifikan. Belum lagi usaha menjegal perubahan itu datang dari DPR sendiri yang notabene adalah bagian dari MPR yang memiliki hak konstitusional merubah konstitusi. Fraksi-fraksi yang sebelumnya mendukung perubahan berbalik menentang perubahan tanpa alasan yang jelas.

Upaya mendorong perubahan konstitusi juga dilakukan untuk kesekian kalinya melalui rapat konsultasi DPD RI dengan Presiden pada awal tahun 2008. Salah satu butir hasil rapat konsultasi itu merekomendasikan urgensi amandemen konstitusi (UUD 1945). Namun tak sedikit pihak yang menentang isu tersebut utamanya dari kolega DPD sendiri di lembaga parlemen, yakni DPR.

Sebagaimana dilaporkan harian Kompas, Selasa, 29 Januari 2008, bahwa kalangan DPR (Sekretaris Fraksi PAN Yasin Kara dan Anggota Fraksi PDI-P Yasonna H. Laloy) menganggap kesepakatan antara Presiden SBY dan DPD RI untuk melakukan perubahan kelima UUD 1945 sebagai pengalihan isu atas kegagalan Pemerintah meningkatkan kesejahteraan rakyat. Kalangan Politisi di DPR menegaskan bahwa tidak tepat mengatakan kegagalan Pemerintah meningkatkan kesejahteraan rakyat disebabkan kelemahan konstitusi.

Selain itu kalangan anggota DPR juga menganggap rencana perubahan tersebut sangat tidak relevan dan tidak tepat waktu sebab usulan perubahan UUD 1945 menjelang Pemilu akan meningkatkan konstelasi suhu politik yang makin panas. Lebih jauh dikatakan bahwa rencana perubahan UUD 1945 adalah skenario di luar tata cara konstitusi yang diatur dalam konsep ketatanegaraan Indonesia. MPR lewat ketuanya

${ }^{15}$ Ni'matul Huda, Op. Cit., hlm. 214. 
Hidayat Nurwahid pun satu suara dengan pendapat yang meminta penundaan perubahan konstitusi untuk waktu yang tidak ditentukan.

Meskipun mendapat banyak penolakan, sampai saat ini DPD RI tetap terus melakukan upaya dan pendekatan dengan rakyat, kalangan akademisi, LSM, Ornop dan lembaga lain untuk mendapatkan dukungan moril dan politis sambil terus menyiapkan konsep perubahan yang akan diusung. Hal itu penting sebab tanpa dukungan publik, perubahan konstitusi hampir mustahil dilakukan. Lebih jauh, dukungan publik dari rakyat, LSM dan organisasi sosial lainnya bisa dijadikan sebagai kekuatan penekan yang akan mengawal proses perubahan konstitusi tersebut.

Harapan kini bergantung kepada sejauh mana Kelompok DPD di MPR melakukan upaya mendorong perubahan konstitusi. Dan yang terlebih penting setelah itu adalah lobi-lobi politik dengan kalangan DPR yang notabene juga anggota MPR sebab dukungan politis dari lembaga itulah upaya mendorong perubahan konstitusi menjadi semakin mudah terwujud. Fakta konstitusional bahwa DPR sebagai mitra strategis DPD RI untuk melakukan amandemen konstitusi tidak terbantahkan bila mengacu pada ketentuan Pasal 37 ayat (1) UUD 1945 yang menyatakan "Usul perubahan pasal-pasal UUD dapat diagendakan dalam sidang MPR apabila diajukan oleh sekurang-kurangnya 1/3 dari jumlah anggota MPR." Mengingat secara kuantitas anggota DPD hanya berjumlah 128 dari 678 anggota MPR maka kemungkinan meloloskan usulan amandemen UUD 1945 hanya dapat diperoleh dengan meraih dukungan dari 226 anggota MPR yang notabene adalah juga anggota-anggota DPR.

Membekali DPD RI dengan kewenangan legislasi yang efektif dan legitimate dengan hanya menggantungkan harapan pada perubahan konstitusi belumlah cukup. Ada hal lebih krusial yang perlu dilakukan yakni perubahan ketentuan dalam UU Susduk yang baru. Perubahan dalam UU Susduk itu menjadi sebuah keniscayaan sebab lewat perangkat Undang-Undang organik itulah kewenangan legislasi itu secara detail diatur lebih lanjut. Momentum menjelang pemilihan umum biasanya dibarengi juga dengan perubahan UU Susduk, maka sudah selayaknya momentum ini bisa dimanfaatkan untuk melakukan pembenahan kewenangan-kewenangan DPD yang dipandang perlu dibenahi.

Momentum penyusunan UU Susduk yang saat ini sedang digodok di DPR harus dimanfaatkan oleh DPD RI sebagai awal perbaikan menuju lembaga parlemen yang efektif. DPD harus aktif melakukan komunikasikomunikasi politik dengan DPR dalam rangka memasukkan kepentingan- 
kepentingan DPD dalam RUU Susduk yang baru. Dalam hal ini kemampun lobi dan komunikasi politik anggota-anggota DPD amat dibutuhkan. Apalagi mengingat kemampuan lobi dan komunikasi politik adalah prasyarat penting menjadi anggota perlemen sebab parlemen sendiri berasal dari bahasa Perancis yaitu parle yang berarti berbicara atau berkomunikasi.

Selama ini DPD cenderung menjadi lembaga yang reaktif dengan berbagai hasil kerja legislasi DPR sehingga tindakan-tindakan proaktifnya dalam rangka memaksimalkan kinerja dan lobi politiknya menjadi terpinggirkan. Hal itu dapat dilihat dari upaya DPD melakukan judicial review terhadap hasil UU yang sudah dirumuskan dan disahkan DPR bersama pemerintah. Padahal dengan memaksimalkan peran lobi politik dengan DPR ketika sebuah RUU itu dibahas akan memudahkan jalan bagi DPD menyisipkan kepentingan-kepentingan yang bersifat kelembagaan. Oleh sebab itulah ketimbang mengajukan judicial review UU Susduk nantinya ke MK setelah disahkan oleh DPR dan Presiden, ada baiknya DPD RI mengefektifkan peran lobi dengan DPR sebagai mitranya di parlemen.

Selain UU Susduk, DPD juga harus memperhatikan perkembangan penyusunan RUU Prolegnas. Prolegnas merupakan proses terpenting dalam perencanaan penyusunan undang-undang. Sebab, berdasarkan prolegnas inilah undang-undang yang akan diprioritaskan dalam periode kerja DPR dan DPD RI disusun.

Pada pasal 16 ayat (1) UU No. 10 Tahun 2004 dinyatakan bahwa penyusunan Prolegnas oleh DPR melalui alat kelengkapan DPR yang khusus menangani bidang legislasi, dalam hal ini adalah Badan Legislasi DPR. Namun yang kemudian menjadi pertanyaan mengapa DPD RI tidak diikut sertakan dalam proses perencanaan Prolegnas?

Secara faktual yuridis, keterlibatan DPD RI dalam penyusunan sebuah RUU yang menjadi kewenangannya mengalami paradoks dan kegamangan. Hal ini karena UU No. 10 Tahun 2004 tentang Pembentukan Peraturan Perundang-Undangan tidak menyebutkan DPD RI sebagai subjek dalam proses perencanaan dan penyusunan Program Legislasi Nasional (prolegnas). Jangankan sebagai subjek penting dalam proses perencanaan dan penyusunan Prolegnas, unsur keterlibatan DPD RI pun tidak disebutkan dalam Undang-Undang tersebut.

Padahal keterlibatan proses perencanaan dan penyusunan Prolegnas menjadi urgen bila mengingat ketentuan Pasal 17 ayat (1) UU No. 10 Tahun 2004 yang mengatur bahwa RUU, baik yang berasal dari DPR, 
Presiden, maupun DPD RI disusun berdasarkan Prolegnas. Bagaimana mungkin ketentuan itu akan mampu ditegakkan oleh DPD RI, jika DPD RI tidak dianggap sebagai subjek penting dalam perencanaan dan penyusunan Prolegnas, padahal setiap RUU dari DPD RI harus berdasarkan Prolegnas. Hal inilah yang menjadi kendala utama DPD RI dalam menjalankan fungsi legislasinya.

Terkait dengan persoalan tersebut, DPD sudah selayaknya melakukan pendekatan-pendekatan baik yang bersifat forma dan informal agar dalam penyusunan rancangan undang-undang tersebut lembaga DPD dapat ditempatkan sebagai salah satu pilar penting pembuat undang-undang tertentu yang berkaitan dengan kepentingan daerah yang menjadi ruh perjuangannya.

Namun upaya pendekatan DPD kepada DPR melalui lobi-lobi politik tidak akan semudah membalikkan telapak tangan. Hal ini disebabkan oleh derajat penerimaan DPD sebagai lembaga yang tidak saja baru tapi juga lembaga sumir yang hampir-hampir tidak memiliki kewenangan strategis.

Selain kemampun lobi yang belum memadai, anggota DPD yang hanya berjumlah 128 anggota DPD tentu akan kesulitan berhadapan dengan 550 anggota DPR sebagaimana diamanatkan dalam konstitusi yang menyebutkan bahwa jumlah anggota DPD tidak boleh melebih dari sepertiga jumlah anggota DPR.

Jumlah yang kecil dibandingkan dengan DPR itu secara faktual makin melemahkan dan mengecilkan makna keberadaan DPD selama ini. Bahkan kalau boleh dikatakan DPD hampir dianggap tidak ada sama sekali atau dalam istilah filosofisnya "adanya seperti tiada, tiadanya seperti ada". Saudara "tua" DPD sendiri, DPR, bahkan menafikan DPD sebagai lembaga parlemen yang mewakili kepentingan rakyat di daerah.

Tak pelak, hubungan antara DPD RI dan DPR kalaulah boleh dikatakan seperti hubungan antara sesosok bayi mungil dengan seorang Bapak yang hendak mengambil satu keputusan dalam rumah tangga. Keberadaan bayi tersebut tentu saja tidak akan "dianggap" sebab selain masih bayi, sosok itu juga tidak bisa dikatakan wujud pengambil keputusan. Itulah yang terjadi selama ini.

Fakta bahwa derajat penerimaan DPD RI sebagai lembaga politik baru amat memprihatinkan bukanlah isapan jempol semata. Hasil kajian Badan Kerja Sama Antar Parlemen (BKSAP) DPR yang disampaikan oleh Wakil Ketua DPR RI Soetardjo Soerjogoeritno melalui surat Nomor: KD.02/ 6439/DPR RI/2005, yang dikirimkan kepada Pimpinan DPD RI secara tegas menyebutkan bahwa "menghindari keikutsertaan DPD dalam forum- 
forum parlemen internasional karena dianggap tidak relevan dengan bidang tugas dan kewenangannya, dan DPD bukan lembaga Parlemen, bukan pula badan legislasi". Hasil kajian BKSAP DPR tersebut secara nyata telah menggodam DPD dan mengkerdilkan keberadaanya secara kelembagaan.

Padahal sikap dan semangat BKSAP tersebut sungguh amat kontraproduktif dengan amanat konstitusi yang menyebutkan bahwa kedaulatan berada di tangan rakyat yang dilaksanakan berdasarkan UUD. Konstitusi secara tegas menyebutkan bahwa MPR terdiri dari anggotaanggota DPR dan DPD. Jika kemudian BKSAP merekomendasikan untuk melakukan pengkerdilan terhadap keberadaan DPD RI, maka bisa dipahami betapa terjalnya jalan yang akan dihadapi DPD dalam melakukan pendekatan dan lobi-lobi politik dengan koleganya di lembaga perwakilan.

\section{Judicial Review UU Pemilu, Paradoks MK dan Wajah ke Depan}

Lahirnya DPD dalam ranah politik ketatanegaraan Indonesia secara langsung maupun tidak langsung telah memetakan aspirasi rakyat menjadi dua poros. Poros pertama adalah aspirasi rakyat secara umum yang diembankan keterwakilannya pada pundak DPR. Poros kedua adalah aspirasi rakyat daerah (teritorial) yang diembankan keterwakilannya pada DPD. Oleh sebab itulah DPR yang diisi oleh orang-orang parpol sering diistilahkan sebagai political representation, sedangkan DPD merupakan regional atau territorial representation. ${ }^{16}$

Namun setelah dikeluarkannya putusan MK terkait gugatan judicial review terhadap UU Pemilu telah mempengaruhi poros dan peta aspirasi rakyat tersebut. Putusan MK yang membolehkan keikutsertaan orangorang parpol mendaftar sebagai anggota DPD sedikit banyak telah mengaburkan aspirasi rakyat yang tadinya terpetakan menjadi aspirasi rakyat secara umum dan aspirasi rakyat daerah. Sebab keberadaan orangorang parpol itu nantinya akan menyulitkan terakomodirnya kepentingan daerah yang diwakili oleh orang-orang parpol tersebut. Orang-orang dari parpol akan sulit menghindari terjadinya benturan kepentingan yang akan diperjuangkan antara kepentingan internal parpol dengan kepentingan daerah yang diwakilinya.

Dalam kehidupan demokrasi modern dewasa ini, peranan badanbadan peradilan menjadi amat vital. Urgensi keberadaan lembaga-lembaga

\footnotetext{
${ }^{16}$ Jimly Asshiddiqie, Op. Cit. hlm. 138.
} 
peradilan seperti MK semakin nyata ketika kompleksitas masalah ketatanegaraan kian hari kian bertambah. Tak mengherankan bila James L. Gibson dan Gregory A. Caldeira mengatakan bahwa konsep demokrasi modern telah menempatkan badan-badan peradilan sebagai penjaga demokrasi. Keduanya mengatakan: ${ }^{17}$

Those responsible for the "Third Wave" of democratization place an extraordinary degree of confidence in judicial institutions as guardians of democracy. Courts are often cast as "veto-players" (see, e.g., Alivizatos 1995)-institutions designed to protect democracy from the excesses of executive power, majority tyranny, corruption, and a myriad of social and political ills.

Terkait dengan konsepsi tersebut maka layak ditanyakan sudah seberapa besarkah pengaruh keberadaan MK dalam mengawal proses demokratisasi di Indonesia. Pertanyaan tersebut mungkin akan terjawab dengan melihat seberapa banyak putusan yang dihasilkan dan atau seberapa efektif dan berdaya guna putusan MK tersebut dalam melakukan peran dan fungsinya sebagai pengawal konstitusi. Namun bila melihat halaman depan Media Indonesia beberapa waktu yang lalu, nampaknya keberadaan MK hanya menimbulkan masalah-masalah baru. ${ }^{18}$ Media Indonesia menurunkan laporan bahwa MK adalah sumber masalah bangsa. Laporan itu mengutip beberapa pendapat pakar hukum tata negara dari Universitas Padjajaran dan Universitas Gadjah Mada. Bahkan beberapa pihak seperti Laode Ida, Wakil Ketua DPD, meminta dievalusinya para hakim MK.

Putusan MK yang dinilai lebih banyak menimbulkan masalah ketimbang menyelesaikan masalah sebenarnya bukanlah tanpa alasan. Putusan MK soal judicial review UU Nomor 10 Tahun 2008 tentang Pemilu misalnya, MK menghapus Pasal 316 huruf d sehingga ketentuan ET 3\% tetap berlaku. Putusan itu dikeluarkan tepat sehari setelah KPU mengumumkan daftar parpol peserta Pemilu yang meloloskan partaipartai kecil selama meraih kursi di Parlemen. Tapi kemudian MK menjelaskan bahwa putusannya itu baru berlaku efektif setelah Pemilu 2009. Tak sedikit yang mempertanyakan apa sebenarnya esensi putusan

${ }^{17}$ James L. Gibson dan Gregory A. Caldeira, "Defending of Democracy? Legitimacy, Popular Acceptance and the South African Constitutional Court", The Journal of Politics, Vol. 65, No 1, Feb. 2003, hlm. 1.

${ }^{18}$ Putusan MK disebutkan lebih cenderung mempertegas kesalahan yang dilakukan para pembuat Undang-Undang dan lebih tunduk pada kepentingan partai politik. Lihat; (Media Indonesia, edisi Sabtu, 12 Juli 2008). 
MK tersebut. Dengan mengandaikan pada logika politik, putusan tersebut sebenarnya sah-sah saja. Namun daya guna putusan tersebut dari teropong logika hukum menjadi hampir-hampir hampa makna. Tak mengherankan bila putusan tersebut memancing reaksi keras banyak kalangan sebab jika MK memutuskan pasal 316 huruf d bertentangan dengan konstitusi maka keikutsertaan partai yang diloloskan namun tidak memenuhi ET 3\% menjadi cacat hukum.

Begitu juga ketika MK mengadili perkara judicial review yang diajukan DPD serta beberapa kelompok masyarakat. MK dihadapkan pada kondisi dilematis sebab gugatan tersebut berisi permohonan agar MK memutuskan ketiadaan syarat domisili dan bukan dari partai dalam syarat pencalonan anggota DPD bertentantangan dengan konstitusi. Sebagai negative judicature, MK hanya berfungsi memutuskan suatu ketentuan dalam undang-undang apakah bertentangan dengan konstitusi atau tidak. Bukanlah menjadi kewenangan MK memutuskan untuk mengadakan suatu ketentuan dalam undang-undang karena itu menjadi tugas pembuat undang-undang. Namun hakim-hakim MK ternyata berpendapat lain. Akhirnya MK memutuskan bahwa ketiadaan syarat domisili bagi calon anggota DPD bertentangan dengan konstitusi. Sedangkan ketiadaan syarat bukan dari kalangan partai politik yang digugat oleh pihak penggugat tidak dikabulkan.

Secara teoritis putusan MK yang menyatakan bahwa domisili merupakan syarat utama bagi mereka yang akan mencalonkan diri menjadi anggota DPD sudah tepat. Sebab dalam praktek demokrasi tak langsung anggota Senat akan lebih efektif dipilih berdasarkan domisili sang calon dan tidak ada larangan calon anggota senat tersebut berasal dari partai politik. Rizang Wrihatnolo mengatakan;

An indirect democracy, which obliges the people to know their representatives, will be more effective if the representatives come from the same region with the voters. This is not like what happens in the unitary state. The candidates for the representatives also live in Jakarta, and most of them do not know the regions they represented". 19

Namun soal keharusan calon anggota DPD bukan dari partai politik memang membutuhkan perdebatan yang hampir tak bertepi. Jika melihat praktek di beberapa negara, Senator, atau bisa disamakan dengan DPD,

${ }^{19}$ Rizang Wrihatnolo, 'Federal State or Unitary State:Indonesia between the choice of Federal State, Unitary State and Decentralization' availbale at: www.bappenas.co.id . Diakses pada tanggal 21 Juli 2008. 
anggota-anggotanya dipilih dan berasal juga dari partai politik. Di Australia misalnya yang mengadopsi sistem Wesminster, sebagaimana dipraktekkan di Inggris, anggota kabinet baik yang berkuasa (eksekutif) maupun kabinet bayangan (oposisi) adalah juga anggota parlemen yang mewakili daerah pemilihannya. Anggota-anggota terpilih lewat pemilu itu duduk di Majelis Rendah (House of Representative) dan lainnya menjadi anggota Majelis Tinggi (Senate) bergelar Senator.

Pasca putusan MK tersebut, beberapa kalangan menilai bahwa ke depan DPD sedikit banyak bakal mengalami perubahan peta politik sebab DPD bisa diisi oleh orang-orang yang notabene aktivis atau pengurus partai politik. Keberadaan kalangan dari partai politik tersebut di DPD paling tidak akan menggenjot popularitas serta kinerja DPD di masa mendatang. Sebaliknya, tak sedikit pula yang beranggapan bahwa putusan MK yang membolehkan orang-orang dari partai politik mencalonkan diri menjadi anggota DPD akan mendistorsi prinsip perwakilan daerah yang menjadi esensi dari keberadaan DPD.

Menyikapi putusan MK tersebut, sejauh ini beberapa tokoh parpol disinyalir telah mencalonkan diri sebagai anggota DPD pada Pemilu 2009. Di antara nama-nama tersebut bermunculan pula sejumlah politisi kawakan yang cukup lama berkecimpung di perpolitikan nasional seperti A.M Fatwa dan Patrialis Akbar dari PAN, Soetardjo Soerjogoeritno dari PDIP serta Rambe Kamarulzaman dari Partai Golkar. Jika nanti terpilih menjadi anggota DPD, sejumlah tokoh parpol itu setidaknya akan memberi warna baru bagi DPD di masa yang akan datang. Kehadirannya tentu saja diharapkan mampu mencerahkan sekaligus memberi suntikan baru bagi mesin politik DPD dalam konstelasi keparlemenan Indonesia. Bagaimana tidak, tokohtokoh parpol yang semula berkecimpung di DPR tersebut tentu saja memiliki kemampuan lobi politik yang bisa menjadi modal penting dalam posisi tawar DPD dengan DPR ketika mereka sudah menjadi bagian dari DPD. Di samping itu kedekatan emosional dengan partai-partai di mana tokohtokoh itu bernaung akan turut memuluskan kerja-kerja DPD ke depannya.

Sebaliknnya, kehadiran orang-orang dari kalangan parpol itu juga berpotensi memberi dampak negatif terhadap keberadaan DPD. Kekhawatiran itu menjadi rasional mengingat calon-calon dari partai politik akan membawa agenda partainya dalam melaksanakan tugas dan fungsinya sebagai anggota DPD. Bagaimanapun kedekatan emosional dengan partai akan membuat independensi anggota DPD sebagai wakil daerah menjadi taruhan besar. Tentu akan sulit menghindari terjadinya 
konflik kepentingan (conflict of interest) antara perannya sebagai wakilwakil daerah di DPD dengan kenyataan mereka juga anggota dari partai politik. Ketua DPD, Ginandjar Kartasasmita berpendapat bahwa profil DPD hasil pemilu 2009 akan berbeda dengan DPD sekarang. Perbedaan itu disinyalir dengan kemungkinan munculnya "fraksi parpol" di lembaga yang mewakili kepentingan daerah tersebut. Paling tidak, menurut Andrinof Chaniago, pengamat politik Universitas Indonesia, kehadiran orang-orang parpol itu akan menimbulkan friksi baru dan akan berpotensi menjadikan DPD sebagai lembaga negara yang mengalami malafungsi. ${ }^{20}$

\section{Penutup}

Sebagai lembaga baru, keberadaan DPD RI secara yuridis konstitusional memang disejajarkan dengan lembaga-lembaga lain seperti DPR, MPR, Presiden, MA, MK, dan BPK. Namun kesejajaran dalam struktur ketatangeraan tersebut tidak dibarengi dengan kesejajaran dalam hal fungsi dan kewenangan. DPD adalah lembaga yang kewenangannya tidak saja 'dibonsai' tapi juga dimarjinalkan secara fungsional dan kelembagaan. Dalam fungsi legislasi, DPD tidak bisa berbuat apa-apa sebab desain konstitusional Indonesia menegaskan bahwa yang memegang kekuasaan membentuk UU adalah DPR. ${ }^{21}$ Dalam fungsi pengawasan, peran DPD juga tidak maksimal, hasil pengawasannya yang diberikan kepada DPR tidak ditindaklanjuti dan dijadikan bahan pertimbangan oleh DPR.

Dalam melaksanakan fungsi dan kewenangan yang terbatas itu, paling tidak ada empat persoalan yang bisa dipetakan dalam menganalisa kendala yang dihadapi DPD selama ini. Pertama, persoalan DPD yang dipicu oleh format kerja dan struktur kelembagaan yang belum memadai. Kedua, persoalan komposisi keanggotaan DPD yang diisi muka-muka baru yang belum teruji kemampuannya dalam melakukan interaksi dan lobi-lobi politik. Ketiga, persoalan lemahnya derajat penerimaan DPD serta political will DPR untuk melibatkan DPD dalam setiap pengambilan keputusan baik yang berkaitan dengan institusi DPD itu sendiri maupun kepentingan dan aspirasi lokal kedaerahan. Akhirnya dan yang paling krusial, DPD

${ }^{20}$ Keberadaan orang-orang parpol dan non-parpol akan memetakan DPD dalam dua poros kekuatan yang potensial memunculkan konflik dalam mekanisme kerja operasional DPP. ( Lihat; Kompas, 11 Juli 2008)

${ }^{21}$ Pasal 20 ayat (1) UUD 1945 setelah perubahan. 
juga mengalami persoalan ketentuan konstitusi dan perangkat undangundang organik yang memposisikan DPD sebagai lembaga yang sumir dengan kewenangan amat terbatas.

Untuk itu agar keberadaan DPD menjadi tidak sia-sia belaka maka perlu disusun langkah-langkah strategis guna memantapkan DPD sebagai ujung tombak perjuangan kepentingan aspirasi-aspirasi lokal. Ke depan, DPD perlu menyusun format kerja dan memantapkan struktur kelembagaan yang akan mendukung kinerja keparlemenan DPD. Sebagai lembaga baru DPD dapat belajar dari lembaga-lembaga negara lain semisal DPR. Di samping itu, DPD juga perlu menigkatkan kapasitas keanggotaannya dalam melakukan kinerja politik demi kepentingan perjuangan aspirasi lokal kedaerahn. Selain itu, DPD juga semestinya terus mengoptimalkan kemampuan lobi dan komunikasi politiknya dengan DPR dalam rangka mewujudkan harmonisasi kelembagaan antara dua lembaga perwakilan tersebut. Derajat penerimaan DPD yang lemah dapat pula ditingkatkan dengan membuktikan kinerja nyata dan hasil-hasil kerja politik yang selama ini belum begitu terlihat di hadapan DPR dan publik. Terakhir dan tak kalah pentingnya, DPD diharapkan tetap konsisten mengupayakan terselenggaranya perubahan konstitusi untuk memperbaiki beberapa ketentuan konstitusi yang menghambat dan mengkebiri keberadaan dan peran DPD dalam lembaga perwakilan Indonesia. Selain itu, DPD juga semestinya aktif melakukan pendekatan kepada DPD khususnya ketika pembahasan RUU susduk dan penyusunan Prolegnas sehingga ketentuan konstitusi tentang fungsi dan kewenangan DPD tidak makin dikerdilkan dalam ketentuan peraturan perundang-undangan.

Persoalan kehadiran orang-orang partai politik dalam DPD pasca pemilu 2009 tentu akan mempengaruhi keberadaan DPD di masa mendatang. Bagaimanapun, keberadaan kalangan partai politik itu harus diapresiasi sebaik mungkin sehingga keberadaannya mampu memompa semangat dan popularaitas DPD dalam memperjuangkan kepentingan-kepentingan daerah.

\section{Daftar Pustaka}

Asshidiqie, Jimly, Konstitusi dan Konstitusionalisme Indonesia,Konpress, Jakarta, 2005

- Hukum Tata Negara dan Pilar-Pilar Demokrasi; Serpihan Pemikiran Hukum Media dan Ham Prof. Jimly Asshiddiqie, Konpress, Jakarta , 2005 
- Perkembangan dan Konsolidasi Lembaga Negara Pasca Reformasi, Konpress, Jakarta, 2006

Berman, Harold J., "The Historical Foundation of Law”, Paper was presented at the Conference on the Foundations of Law held at Emory Law School, March 25, 2004.

Bertrand, Jacques, "Indonesia's quasi-federalist approach: Accommodation amid strong integrationist tendencies" ,2007

Budiarjo, Miriam, Dasar-Dasar Ilmu Politik, Jakarta, 1993

DPD RI, Sekretariat, Bikameral Bukan Federal, Jakarta, 2005

- Kerja Politik Untuk Kesejahteraan Masyarakat dan Daerah; Rencana Kerja Strategis Dewan Perwakilan Daerah Republik Indonesia, Sekjend DPD, Jakarta, 2006

DPD, Kelompok di MPR RI, Untuk Apa DPD RI, Sekjend DPD, Jakarta, 2005

Elazar, Daniel J., "Covenant and Civil Society - The Constitutional Matrix of Modern Democracy" ,1998

Erawan, I Ketut, 'Political Reform and Regional Politics in Indonesia', Asian Survey, (1999) Vol. 39 No. 4

Finklestein, Lawrence S., “The Indonesian Federal Problem”, Pacific Affairs, 1951

Friedrich, C.J., Constitutional Government and Democracy, 1967

Gaffar, Jenedri M. dkk (ed), Dewan Perwakilan Daerah, Jakarta, 2003

Hamilton, Walton H. , 'Constitutionlism', Ensyclopedia of Social Science, 1930

Huda, Ni'matul, Lembaga Negara dalam Masa Transisi Demokrasi,UII Press, Yogyakarta, 2007

Kahin, George M., "Nationalism, and Revolution in Indonesia", (1952)

Kasper, Wolfgang, 'Australia's Hollow Federalism: Can We Revive Competitive Governance?', Institute of Public Affairs Review Oct 2007, Vol. 59 Issue 3.

Lee HP and Winterton, G, “Australian Constitutional Landmarks", (2003)

Lijpart, Arend, "Constitutional Design for Divided Societies", Journal of Democracy (2004)

Mahfud MD, Moh., Politik Hukum di Indonesia, LP3ES, Jakarta (1998) Amandemen Konstitusi Menuju Reformasi Tata Negara, LP3ES, Jakarta ,1999

, Perdebatan Hukum Tata Negara, LP3ES, Jakarta, (2007)

Mcllwain, Charles H., Constitutionalism; Ancient and Modern, New York ,1966

Post, Robert, 'Democratic Constitutinalism and Cultural Heterogeneity', Australian Journal of Legal Philosophy, 2000 
Thaib, Dahlan, Hamidi, Jazim, Huda, Ni'matul, Hukum dan Teori Konstitusi,Rajawali Press, Jakarta, 2004

Soetandyo Wignosoebroto, dalam Bambang Sunggono, Metodologi Penelitian Hukum, Jakarta, 1997

Strong, C. F, Modern Poltical Constitution, 1996

Subekti, Valina Singka, Menyusun Konstitusi Transisi, Raja Grafindo, Jakarta, 2008

Sunder, Madhavi, 'Enlightened Constitutionalism', School of Law the University of California, 2005

Risalah Sidang BPUPKI-PPKI 28 Mei-22 Agustus 1945, Jakarta, Sekretariat Negara Republik Indonesia, 1995.

Risalah Sidang PAH I BP MPR Tahun 2000, Sekretariat Jenderal MPR-RI. Risalah Sidang PAH I BP MPR Tahun 2001, Sekretariat Jenderal MPR-RI. Risalah Sidang PAH I BP MPR Tahun 2002, Sekretariat Jenderal MPR-RI. Harian Kompas Harian Kedaulatan Rakyat Harian Rakyat Merdeka Harian Media Indonesia

Majalah Tempo

Wrihatnolo, Rizang, 'Federal State or Unitary State: Indonesia between the choice of Federal State, Unitary State and Decentralization' available at: www.bappenas.co.id. Viewed at 28 of December 2007.

Antlov, Hans, 'In Indonesia: Disentangling the Confusion about Federalism', Jakarta Post, June, 3, 1999. Available at: www.thejakartapost.com/index/php/02061999/html.

www.jstor.org.

www.dpd.go.id

www.dpr.go.id

www.mahkamahkonstitusi.go.id

www.jimly.com 